\title{
Moral Damages as an 'Exceptional' Remedy in International Investment Law - Re-Connecting Practice with General International Law
}

\author{
Robert Christoph Stendel ${ }^{*}$ \\ Max Planck Institute for Comparative Public Law and International Law, \\ Heidelberg, Germany \\ stendel@mpil.de
}

Abstract

Keywords

I. Moral Damages Under International Investment Law - The Legal Framework 943

1. Jurisdiction to Award Moral Damages 943

2. The Substantive Rules Applicable to Moral Damages 945

a) Moral Damages Under General International Law 945

b) Corporate Claimants and Moral Damages 948

II. Moral Damages and International Investment Law - A Disputed Arbitral Practice 949

1. Arbitral Awards on Moral Damages - Exceptional Circumstances as a Precondition for Moral Damages

a) Exceptional Circumstances in Arbitral Practice 949

b) Arbitral Practice not Referring to Exceptional Circumstances 952

c) The Contours of Exceptional Circumstances 954

2. The Discontents of the Critique in the Literature 956

III. Reconciling Exceptional Circumstances with International Law 958

1. An Implicit Exceptional Circumstances Standard Under General International Law?

2. Exceptional Circumstances as an Emerging Rule of Customary International Law 961

a) The Emergence of a New Rule of Customary International Law 961

b) The Rationale Behind the Rule $\quad 965$

IV. Conclusion $\quad 967$

\begin{abstract}
Moral damages under international investment law have been extensively addressed in the literature. Notoriously, arbitral tribunals have subjected any claim for moral damages to a requirement unknown to general international law, that is exceptional circumstances. This practice is widely criticised in the field mainly due to the seeming inconsistency with general international law.

* Ass. jur., MJur (Oxford); Research Fellow at the Max Planck Institute for Comparative Public Law and International Law, Heidelberg, Germany.

The author would like to thank Fabian Eichberger, Richard Dören and Alexander Wentker for their invaluable comments on prior versions of the manuscript.
\end{abstract}


This article challenges this view by arguing that a deviation from general international law does not - in and of itself - suffice to discard the tribunals' approach. This argument is based on the insight that general international law only deals with inter-State responsibility and is, thus, open to deviations from general international law in case of State responsibility vis-à-vis the individual. On that basis, the article explores possible legal bases for exceptional circumstances in international law. While it discards the idea that such a requirement for awarding moral damages is implicit in prior inter-State cases, the article rather argues that the arbitral practice witnesses the emergence of a new rule of customary international law applicable to the responsibility of a State vis-à-vis the individual. Thereby, the article seeks to contribute to the wider debate on the content and contours of State responsibility for claims of the individual.

\section{Keywords}

State responsibility - individuals in international law - moral damages international investment law - exceptional circumstances - Desert Line v. Yemen - Lemire v. Ukraine

Moral damages, that is the financial compensation for (human) suffering, harm, or any immaterial loss of reputation, ${ }^{1}$ are firmly rooted in public international law. ${ }^{2}$ Also under international investment law (IIL), moral damages have been awarded in some investment disputes ${ }^{3}$ and claimed in even more cases. ${ }^{4}$ Given the clear basis under international law, it is perhaps surprising that moral damages attracted considerable attention in recent literature on IIL. ${ }^{5}$ This inter-

1 Lars Markert and Elisa Freiburg, 'Moral Damages in International Investment Disputes On the Search for a Legal Basis and Guiding Principles', The Journal of World Investment \& Trade 14 (2013), 1-43 (3).

2 See, e.g. PCA, Arctic Sunrise Arbitration (Netherlands v. Russia), award on merits, 14 August 2015, case no. 214-02, para. 394. However, the standards for ascertaining the amount of moral damages is less settled under international law, see PCA, Arctic Sunrise Arbitration (Netherlands v. Russia), award on compensation, 10 July 2017, case no. 2014-02, para. 82.

3 ICSID, Desert Line Projects LLC v. Yemen, award of 6 February 2008, case no. ARB/05/ 17, para. 290; ICSID, Rüdiger von Pezold et al. v. Zimbabwe, award of 28 July 2015, case no. $\mathrm{ARB} / 10 / 15$, paras $921,923$.

4 See infra II.1.

5 See the most recent publications: Patrick Dumberry, 'Moral Damages' in: Christina L. Beharry (ed.), Contemporary and Emerging Issues in the Law of Damages and Valuation in International Investment Arbitration (Leiden and Boston: Brill Nijhoff 2018), 142-167; Subhiksh Vasudev, 'Damages for Non-Material Harm in Investment Treaty Arbitration', ASA Bulletin 37 (2019), 97-110; Simon Weber, 'Demystifying Moral Damages in International Investment Arbitration', The Law and Practice of International Courts and Tribunals 19 (2020), 417-450; Leonard von Bargen, Rechtsfortbildung durch Investitionsschiedsgerichte (Baden-Baden: Nomos 2020). 
est is driven by several factors of which one will be the focus of this article. As I will map out, an ever-growing arbitral practice has emerged, which conditions an award of moral damages upon exceptional circumstances. This standard essentially requires a certain gravity of the respondent State's conduct as a precondition for awarding pecuniary damages for moral harm. ${ }^{6}$ Yet, such requirement has never been (explicitly) ${ }^{7}$ acknowledged by any court or tribunal under international law outside $\mathrm{IIL}^{8}$ and most investment law tribunals failed to justify their approach in anything else than prior decisions. ${ }^{9}$ Against the backdrop of general international law, this paucity of reasoning quite naturally attracted the interest of scholars. Indeed, most commentators rejected the approach of arbitral practice to require an additional (and higher) threshold for awarding moral damages for a lack of basis in international law. ${ }^{10}$ Even voices sympathetic to arbitral practice have been careful to point out that it does not reflect international law as it stands. ${ }^{11}$

6 ICSID, Joseph Charles Lemire v. Ukraine, award of 28 March 2011, case no. ARB/06/18, para. 326; see further infra II.1.c).

7 See infra III.1 on possible arguments on general international law's compatibility with such a criterion.

8 See Dumberry (n. 5), 157; see further infra I.2.a).

9 See, e. g. ICSID, Señor Tza Yap Shum v. The Republic of Peru, award of 7 June 2011, case no. ARB/07/6, para. 281. However, in Lemire v. Ukraine, the tribunal also referred to 'most legal systems' to support its conclusion on the availability of moral damages, see ICSID, Joseph Charles Lemire v. Ukraine, Decision on Jurisdiction and Liability of 14 January 2010, case no. ARB/06/18, para. 476. Notably, the tribunal does not invoke this argument to justify the exceptional circumstances standard.

10 See Dumberry (n. 5), 157; Irmgard Marboe, 'Damages in Investor-State Arbitration: Current Issues and Challenges', International Investment Law and Arbitration 2 (2018), 1-86 (59 and 64); see also Conway Blake, 'Moral Damages in Investment Arbitration: A Role for Human Rights?', Journal of International Dispute Settlement 3 (2012), 371-407 (394 et seq.); Patrick Dumberry and Sébastien Cusson, 'Wrong Direction: "Exceptional Circumstances" and Moral Damages in International Investment Arbitration', Journal of Damages in International Arbitration 1 (2014), 33-75 (54); Bernd Ehle and Martin Dawidowicz, 'Moral Damages in Investment Arbitration, Commercial Arbitration and WTO Litigation' in: Jorge A. HuertaGoldman, Antoine Romanetti and Franz X. Stirnimann (eds), WTO Litigation, Investment Arbitration and Commercial Arbitration (Alphen aan den Rijn: Kluwer Law International 2013), 293-326 (307); Juan Pablo Moyano García, 'Moral Damages in Investment Arbitration - Diverging Trends', Journal of International Dispute Settlement 6 (2015), 485-521 (501-503); John R. Laird, 'Moral Damages and the Punitive Question in ICSID Arbitration', ICSID Review (2011), 171-183 (183); Vasudev (n. 5), 107 et seq.; see also Markert and Freiburg (n. 1), 30-32; cf. however, Jarrod Wong, 'The Misapprehension of Moral Damages in Investor-State Arbitration' in: Arthur W. Rovine (ed.), Contemporary Issues in International Arbitration and Mediation - The Fordham Papers 2012 (Leiden and Bosten: Brill Nijhoff Publishers 2012), 6799 (89) who describes the assessment in Lemire v. Ukraine as a 'fair distillation of the caselaw'.

11 Weber (n. 5), 447. 
As I will show in this article, the arbitral practice grew regardless of scholarly criticism and without paying any heed to it. ${ }^{12}$ Given the great weight accorded to prior decisions by arbitral tribunals in IIL, ${ }^{13}$ the position in the literature seems difficult to defend. Yet, this does not absolve from the task to find a legal basis, which is yet unresolved. It is this gap the article seeks to close by arguing that the exceptional circumstances standard has a legal basis in international law.

To this end, the article will explore two alternative bases for an exceptional circumstances standard. First, the article will consider whether a close analysis of inter-State cases supports the conclusion that general international law already contains an implicit exceptional circumstances standard. Secondly, and alternatively, it will assess the potential of arguing that exceptional circumstances reflect an emerging rule of customary international law within the realm of IIL. I will argue that the latter approach is more plausible for principled reasons ${ }^{14}$ and thus, exceptional circumstances are well founded in public international law.

Finding a basis for the exceptional circumstances standard is more than just a theoretical endeavour. This is so because international law does not know a doctrine of stare decisis and judicial opinions are only subsidiary sources of international law. ${ }^{15}$ Accordingly, the simple fact of a consistent practice does not do, however uniform it may be. Rather, any judicial pronouncement must be rooted in one of the sources of international law. Put differently, international courts and tribunals are tasked to apply the law, and not to legislate. ${ }^{16}$ Of course, any application of a legal rule may involve

12 See Dumberry and Cusson (n. 10), 54 ('This trend [in arbitral practice] is all the more surprising considering that this interpretation has been rejected (to the best of our knowledge) by all writers who have recently examined the question of moral damages in the specific context of investor State arbitration.').

13 See on the emergence of a what might be called a de-facto policy of stare decisis: Stephan W. Schill, The Multilateralization of International Investment Law (Cambridge: Cambridge University Press 2009), 355 et seq. ('Finally, some of the standard investor rights [...] are actually primarily forged by precedent, not by reference to other sources of international law or State practice. Far from constituting merely a subsidiary source of international law, precedent in these cases assumes the function of a primary source of international law.'); see also Florian Grisel, 'The Sources of Foreign Investment Law' in: Zachary Douglas, Joost Pauwelyn and Jorge E. Viñuales (eds), The Foundations of International Investment Law - Bringing Theory Into Practice (Oxford: Oxford University Press 2014) 213-233 (233) arguing that arbitral practice has produced a 'common law of foreign investment', viz. a system of de-facto binding precedent.

14 See infra III.1.

15 Art 38(1)(c) ICJ Statute, see also Hugh Thirlway, The Sources of International Law (Oxford: Oxford University Press 2014), 117 and 120-122.

16 See ICJ, Legalitiy of the Threat or Use of Nuclear Weapons, advisory opinion of 8 July 1996, I. C. J. Reports 1996, 226, para 18. 
an element of law making ${ }^{17}$ and drawing boundaries between rather uncontroversial activities such as clarifying rules or filling (perceived) gaps, ${ }^{18}$ and instances perceived as judicial activism without a sufficient legal basis is intrinsically difficult. However, this is not to say that we must yield to tribunals' pronouncements unconditionally. Crucially, the case of exceptional circumstances seems to be one where arbitral practice seems to have added an additional requirement, arguably without any legal basis, which is qualitatively different from, say, further elucidating the level of reparation due or the amount of compensation. In and of itself, this calls for a closer look at the possible legal bases of the exceptional circumstances standard. On a more general note, it is worth noting that damages awards are the most visible part of an award for the public. Thus, deficits in their reasoning and basis can have a significant impact on arbitral tribunals' and IIL's legitimacy. ${ }^{19}$ Consequently, at least for a tribunal's authority and legitimacy, it is of paramount importance to limit tribunal's powers and, conversely, locate the decisions within these boundaries.

In addition, the search for a legal basis can help to develop the still rudimentary law of State responsibility vis-à-vis the individual in general by re-connecting the developments in IIL with the general law of State responsibility under customary international law. As is often overlooked, the International Law Commission (ILC) Articles on the Responsibility of States for International Wrongful Acts (ARSIWA) ${ }^{20}$ do not govern the content of a State's responsibility vis-à-vis an individual (Art. 33(2) ARSIWA), but are limited to inter-State claims in that respect. Nevertheless, tribunals routinely apply the ARSIWA to individual claims ${ }^{21}$ while commentators caution that this application has to adapt to the specifics of an individual's claim. ${ }^{22}$ Yet, it is still quite unclear what this means in practical terms. Consequently, there is a need to elaborate the specific content of State responsibility towards the individual. Here, rooting the arbitral practice on moral damages in IIL in an

17 Hans Kelsen, Introduction to the Problems of Legal Theory (Oxford: Clarendon 1997), 70.

18 See Gleider Hernández, 'International Judicial Lawmaking' in: Catherine Brölmann and Yannick Radi (eds), Research Handbook on the Theory and Practice of International Lawmaking (Cheltenham: Edward Elgar 2016), 200-221 (201).

19 See Thomas Wälde and Borzu Sabahi, 'Compensation, Damages and Valuation' in: Peter Muchlinski, Federico Ortino and Christoph Schreuer (eds), The Oxford Handbook of International Investment Law (Oxford: Oxford University Press 2008) 1049-1124 (1054).

20 International Law Commission, Draft Articles on the Responsibility of States for Internationally Wrongful Acts with Commentaries of 2001, ILCYB 2001, Vol. II, Part Two, 31.

21 See infra II.2.

22 See Anne Peters, Beyond Human Rights (Cambridge: Cambridge University Press 2016), 174; see further infra II.2. 
emerging rule of customary international law and linking it with the general law of State responsibility may clarify the emerging customary rules on reparation for the individual. Thereby, this article also seeks to contribute to the wider debate on the content of state responsibility vis-à-vis the individual. It does so by proposing to understand the arbitral practice as a development towards a more nuanced approach to damages for the individual, ${ }^{23}$ which does not transpose the inter-State law of State responsibility 'lock, stock, and barrel'24, but respects the peculiarities of individual claims. As I will argue, the exceptional circumstances standard can be read as just such an adaptation of the law of State responsibility to individual claims.

The argument proceeds in three steps. First, the article will set the scene by briefly analysing, the basis, applicable law, and the limits for awarding moral damages under IIL. After all, moral damages are entangled with many more problems under IIL, such as jurisdiction, ${ }^{25}$ moral damages for the respondent State, ${ }^{26}$ or for harm suffered by a corporation's employees, ${ }^{27}$ which I can only address in a cursory fashion here. Against this backdrop, the article then analyses the arbitral practice on moral damages under IIL in a second step. As will be shown, this practice introduced a threshold for moral damages, which is mostly criticised in the literature. However, this criticism is based on an incorrect assumption, that is the necessary similarity between interState and individual claims. Given also the consolidation of arbitral practice, I will thirdly argue that the exceptional circumstances standard can be grounded in international law. Based on prior international decisions, I will explore general international law's compatibility with an exceptional circumstances standard. Despite its merits, this approach is difficult to reconcile with one of the overarching principle of state responsibility, full reparation, ${ }^{28}$ and thus, I will suggest that the arbitral practice rather reflects an emerging rule of customary international law. Ultimately, this rule reflects the specific circumstances of individual claim mechanisms. In particular, one of these characteristics is allowing for potentially large numbers of claimants as well

23 This article uses 'individual' in a broad sense to include individual human beings, as well as corporate investors which international law endows with limited international rights. The term is used as the counterpart to State.

24 ICJ, International Status of South West Africa, Separate Opinion Sir Arnold McNair of 11 July 1950, I.C. J. Reports 1950, 146, 148.

25 See infra I.1.

26 Inna Uchkunova and Oleg Temnikov, 'The Availability of Moral Damages to Investors and to Host States in ICSID Arbitration', Journal of International Dispute Settlement 6 (2015), 380-402 (387-402).

27 Borzu Sabahi, Compensation and Restitution in Investor-State Arbitration (Oxford: Oxford University Press 2011), 319 et seq.; see further infra n. 66.

28 Art. 31 para. 1 ARSIWA. 
as claims (different from the earlier inter-State mechanism of diplomatic protection $)^{29}$ and thereby triggering the need make these demands manageable. In limiting the availability of moral damages to certain situations, international law exhibits its capability to develop a more nuanced regime of State responsibility towards the individual.

\section{Moral Damages Under International Investment Law - The Legal Framework}

Since analysing an additional criterion for awarding moral damages necessarily requires the general availability of moral damages, I will briefly discuss a tribunal's jurisdiction to award moral damages, the applicable rules (and their content), and their application to corporate claimants in investment disputes under public international law. For the sake of clarity, moral damages (using the plural) are a specific form of reparation for moral harm (or damage in the singular), more precisely its pecuniary compensation. ${ }^{30} \mathrm{Be}-$ sides, moral harm is understood to be synonymous with non-pecuniary and non-material harm. ${ }^{31}$

\section{Jurisdiction to Award Moral Damages}

Regarding jurisdiction, the starting point of any analysis is the clause providing for a tribunal's jurisdiction, which may be found in an investment code, an investment contract, or in an International Investment Agreement (IIA). ${ }^{32}$ If there is no treaty language to exclude their jurisdiction on moral

29 Of course, claims brought by way of diplomatic protection can be numerous (e. g. before the US-Germany Mixed Claims Commission). However, in contrast to these instances, the characteristic of individual claims mechanisms lies in the fact that they cover a yet unknown set of cases while Claims Commissions concerned a distinct event of the past.

30 See on 'damage', 'harm', and 'damages' under general international law and the European Convention on Human Rights, Szilvia Altwicker-Hámori, Tilmann Altwicker and Anne Peters, 'Measuring Violations of Human Rights - An Empirical Analysis of Awards in Respect of Non-Pecuniary Damage under the European Convention on Human Rights', ZaöRV/HJIL 76 (2016), 1-51 (5-9). Cf. on the distinct term of injury which refers to the illegality of an act, Stephan Wittich, 'Non-Material Damage and Monetary Reparation in International Law', FYBIL 15 (2004), 321-368 (323-326).

31 See on the terminology Wittich (n. 30), 329-331 (preferring the term 'non-material damage').

32 If the arbitration is subject to the ICSID Convention, additional requirements must be met, such as those under Art. 25 Convention on the Settlement of Investment Disputes between States and Nationals of Other States of 18 March 1965, 575 UNTS 519. 
damages, tribunals have found themselves competent to award moral damages. ${ }^{33}$ Indeed, this is a plausible application of international case law. As the Permanent Court of International Justice (PCIJ) in the seminal Chorzów Factory Case held in the jurisdictional phase, a compromissory clause in a treaty also encompasses disputes on reparation. ${ }^{34}$ Taken together with the equally famous statement on the merits 'that reparation must, as far as possible, wipe out all the consequences of the illegal act' ${ }^{35}$ it follows that a tribunal must also be competent to decide on moral damages in order to provide full reparation.

In contrast, commentators have suggested that a tribunal will only be competent to hear claims for moral damages if the IIA also expressly protects the investor (and not only the investment) because moral damages are closely related to the investor as a person. ${ }^{36}$ It seems that so far only one tribunal in a recent, but unpublished award relied on this argument to decline jurisdiction. ${ }^{37}$ Hence, it remains to be seen whether this award changes arbitral practice's position in this regard. For the time being, it is fair to assume that tribunals possess jurisdiction to remedy moral harm based on the approach advocated by the PCIJ.

33 ICSID, Desert Line v. Yemen (n. 3), para. 289 ('There are indeed no reasons to exclude them.'); ICSID, Cementownia 'Nowa Huta' S. A. v. Republic of Turkey, award of 17 September 2009, ICSID case no. ARB(AF)/06/2, para. 169 (citing Desert Line); ICSID, Lemire v. Ukraine (n. 9), para. 476 (also citing Desert Line); similarly ICSID, OI Europe Group B. V. v. Bolivarian Republic of Venezuela, award of 10 March 2015, case no. ARB/11/25, para. 906; Blake (n. 10), 374; Dumberry and Cusson (n. 10), 35; Marc Allepuz, 'Moral Damages in International Investment Arbitration', Spain Arbitration Review 17 (2013), 5-15 (7 et seq.).

34 PCIJ, Case Concerning the Factory at Chorzów (Jurisdiction), judgment of 26 July 1927, Series A no. 9, 4, 21.

35 PCIJ, Case Concerning the Factory at Chorzów (Germany v. Poland), merits, judgment of 13 September 1928, Series A, no. 17, 4, 47.

36 See on this argument Stephen Jagusch and Thomas Sebastian, 'Moral Damages in Investment Arbitration: Punitive Damages in Compensatory Clothing?', Arbitration International 29 (2013), 45-62 (55 et seq.) who take a critical stance; see generally for a critical view on the existence of a sufficient link between the investment and moral damages Eric De Brabandere, Investment Treaty Arbitration as Public International Law (Cambridge: Cambridge University Press 2014), 198; see also Ingeborg H. Schwenzer and Pascal Hachem, 'Moral Damages in International Investment Arbitration' in: Stefan Kröll, Loukas A. Mistelis and María del Pilar Perales Viscasillas (eds), International Arbitration and International Commercial Law (Alphen aan den Rijn: Kluwer Law International 2011), 411-430 (419 et seq.) bringing the argument on a substantive level when analysing the violation of an IIA guarantee.

37 ICSID, Güneş Tekstil Konfeksiyon Sanayi ve Ticaret Limited Şirketi and Others v. Uzbekistan, case no. ARB/13/19, see the report by Cosmo Sanderson, 'Uzbekistan Liable for Seizure of Shopping Mall', Global Arbitration Review (2019). 


\section{The Substantive Rules Applicable to Moral Damages}

Investment arbitrations are subject to a variety of legal regimes. ${ }^{38}$ While this may involve the application of municipal law, this article is only concerned with instances where public international law governs a claim for moral damages, i.e. when the underlying violation is one of public international law. If this is the case, reparation is subject to the rules of general international law unless the treaty provides for specific rules on reparation. Yet, such rules are very $\operatorname{rar}^{39}$ and most of them only exclude specific remedies, such as punitive damages or occasionally also moral damages, ${ }^{40}$ whereas only very few provide for comprehensive rules on reparation. ${ }^{41}$ Thus, reparation under IIL is mostly subject to the general international law rules, ${ }^{42}$ which are largely uncodified due to their customary nature. However, most of these rules are reflected in the ARSIWA. ${ }^{43}$

Accordingly, I will first set out the rules applicable to moral damages under general international law to map out the framework for such claims (a). Because IIL often sees corporate claimants and moral damages are, at first sight, difficult to reconcile with a corporation, I will then briefly discuss to which extent a corporate claimant may recover moral harm under international law (b).

\section{a) Moral Damages Under General International Law}

Under general international law, moral damages are a well-accepted form of reparation for non-material harm ever since the seminal Lusitania Opinion

38 See Art. 42 ICSID Convention.

39 Sabahi (n. 27), 138.

40 See Art. 21 para. 3 Agreement between the Slovak Republic and the Islamic Republic of Iran for the Promotion and Reciprocal Protection of Investments of 19 January 2016, available at <https://investmentpolicy.unctad.org >, Art. 14.10 (iii) Model Text for the Indian Bilateral Investment Treaty of 2016, available at: <https://www.mygov.in>; Q. para. 4 Model Agreement of the Belgium-Luxembourg Economic Union on the Reciprocal Promotion and Protection of Investments of 2019, available at: <https://www.lachambre.be>. This approach is in line with policy recommendations by UNCTAD, see United Nation's Conference on Trade and Development, Investment Policy Framework for Sustainable Development of 2015, available at: $<$ http://investmentpolicyhubunctadorg/ipfsd>, 109.

41 Cf. Art. 8.39 Comprehensive Economic and Trade Agreement (CETA) between Canada and the EU and Its Member States of 30 October 2016, OJ L 11/23, 14 January 2017.

42 See, however, for possible differences Zachary Douglas, 'Other Specific Regimes of Responsibility: Investment Treaty Arbitration and ICSID' in: James Crawford, Alain Pellet and Simon Olleson (eds), The Law of International Responsibility (Oxford: Oxford University Press 2010), 815-842 (829-832).

43 See James Crawford and Simon Olleson, 'The Application of the Rules of State Responsibility' in: Marc Bungenberg, Jörn Griebel, Stephan Hobe and August Reinisch (eds), International Investment Law - A Handbook (Baden-Baden: Nomos 2015) 411-441, para. 14. 
by the US-Germany Mixed Claims Commission (MCC) in 1923.44 This decision is often thought to be the first reasoned examination of moral damages in international $\mathrm{law}^{45}$ and addressed the claims arising out of the sinking of the passenger ship Lusitania by a German submarine in 1915. Among other things, the Umpire held that a State may recover moral damages expressly relying on French and American court practice. ${ }^{46}$ Until today, Lusitania is still 'the' leading case on moral damages. ${ }^{47}$ Notably, also investment tribunals cite Lusitania as the leading case. ${ }^{48}$ The reference to French law in Lusitania ('prejudice morale') 49 also explains the usage of the term 'moral damages' in international law. ${ }^{50}$ Based on Lusitania, moral damages have become part of customary international law. ${ }^{51}$

Notwithstanding uncertainties as to the amount of moral damages due,52 moral damages are construed quite broadly and without any explicit indication of a threshold of gravity. For instance, the ARSIWA define moral damages broadly as 'loss of loved ones, pain and suffering as well as the affront to sensibilities associated with an intrusion on the person, home or private life'. ${ }^{53}$ Already back in Lusitania, moral damages covered diverse forms of moral harm ('mental suffering, injury to his feelings, humiliation, shame, degradation, loss of social position or injury to his credit or to his reputation' $)^{54}$ without indicating any minimum threshold. In Diallo, the International Court of Justice (ICJ) went even further and did not even require any specific evidence for moral harm, opining that 'the fact that he suffered non-material injury is an inevitable consequence of the wrongful acts of the DRC'. ${ }^{55}$ Perhaps a bit more cautious, the International Tribunal for the Law of the Sea (ITLOS) in the $M / V$ Saiga case held that an award for

44 US-Germany Mixed Claims Commission, Opinion in the Lusitania Cases, decision of 1 November 1923, VII UNRIAA 32.

45 See Markert and Freiburg (n. 1), 8 et seq.

46 US-Germany Mixed Claims Commission, Lusitania (n. 44), 37.

47 See, e.g. ICJ, Abmadou Sadio Diallo (Guinea v. Democratic Republic of the Congo), compensation, judgment of 19 June 2012, I.C. J. Reports 2012, 324 (para. 18).

48 See, e. g. Desert Line (n. 3), para. 289; Lemire v. Ukraine (n. 6), para. 329 et seq.; ICSID, Franck Charles Arif v. Republic of Moldova, award of 8 April 2013, case no. ARB/11/23, para. 591.

49 US-Germany Mixed Claims Commission, Lusitania (n. 44), 36.

50 Jagusch and Sebastian (n. 36), 47.

51 See ICJ, Diallo, compensation (n. 47), para. 18. The ICJ did not address the legal status of moral damages. Indeed, one may also construe moral damages as a general principle within the meaning of Art. 38(1)(c) ICJ Statute, Markert and Freiburg (n. 1), 27 et seq.

52 See, e. g. the assessment in PCA, Arctic Sunrise, Compensation (n. 2), para. 82.

53 ILC, ARSIWA with commentaries (n. 20), Art. 36 para. 16.

54 US-Germany Mixed Claims Commission, Lusitania (n. 44), 40; cited with approval in ICJ, Diallo, compensation (n. 47), para. 18.

55 ICJ, Diallo, compensation (n. 47), para. 21. 
moral damages would depend on the circumstances of the case, which 'include such factors as the conduct of the State which committed the wrongful act and the manner in which the violation occurred'. ${ }^{56}$ While the emphasis on the manner of the violation might suggest that not every moral harm caused by a wrongful act warrants damages, the tribunal neither pronounced an exhaustive list of requirements for awarding moral damages nor expressly subjected moral damages to an exceptional circumstances standard. As the conduct of the liable State is a relevant factor to assess the amount of moral damages due, ${ }^{57}$ this phrase could equally refer to the amount due. Thus, it seems fair to conclude that general international law provides that any moral damage must be compensated. There is no indication of an explicit additional requirement in order to allow a tribunal to order the payment of moral damages. ${ }^{58}$

For my argument relies on the differences between State responsibility for inter-State claims and for individual claims, it is well worth noting that moral damages have emerged as a concept in an inter-State context, despite the fact that they in fact remedy individual harm. As is generally the case in interState cases, e. g. in Lusitania ${ }^{59}$, the State brings a claim for moral damages by way of diplomatic protection on behalf of its nationals. Traditionally, it was mostly thought that a State asserted its own primary and especially secondary rights (to damages), not those of its national. ${ }^{60}$ Similarly, Diallo and $M / V$ Saiga concerned the exercise of diplomatic protection. ${ }^{61}$ Thus, the awards essentially deal with claims between States, which is a notable difference to IIL and other areas of public international law of a more recent vintage that recognise individual rights and allow individuals to make claims on their own behalf.

In addition, moral damages only comprise the moral harm suffered by an individual and not the moral or immaterial harm suffered by a State (even if only the State is usually empowered to bring the claim by way of diplo-

56 ITLOS, M/V Saiga Case, St. Vincent and the Grenadines v. Guinea, judgment of 1 July 1999, case no. 2, para. 171.

57 See Gaetano Arangio-Ruiz, Second Report on State Responsibility (1989), A/CN4/425 \& Corr1 and Add1 \& Corr1, para. 180.

58 Dumberry (n. 5), 157; see, e. g. for awards which do not pronounce such a requirement: PCA, Arctic Sunrise Merits (n. 2), para. 394; PCA, Duzgit Integrity Arbitration, award on reparation of 18 December 2019, case no. 2014-07, paras 180, 183; PCA, The 'Enrica Lexie' Incident (Italy v. India), award of 21 May 2020, case no. 2015-28, para. 1088.

59 This was the case in Lusitania (MCC, Administrative Decision No. 2, decision of 1 November 1923, VII UNRIAA 23, 26) as well as e. g. in Diallo (ICJ, Diallo, compensation (n. 47), para. 13).

60 Peters (n. 22), 390.

61 See ICJ, Diallo, compensation (n. 47), para. 13; ITLOS, M/V Saiga (n. 56), paras 105-109 (exercise of diplomatic protection by the flag State). 
matic protection). The latter is only subject to satisfaction under Art. 37 ARSIWA.62

All in all, under general international law, moral damages form part of the reparation due to a State under the customary law of State responsibility. It is widely accepted and there are no explicit threshold-requirements to award pecuniary damages for moral harm.

\section{b) Corporate Claimants and Moral Damages}

Moral damages are closely tied to the human being not least because they are meant to remedy harm and suffering. ${ }^{63}$ However, under IIL, corporate claimants are the rule. Thus, one wonders whether moral damages are of any practical relevance under IIL. Yet, such concerns are unfounded because some aspects of moral damages also apply to corporate investors without any doubt. In particular, a corporation may easily suffer a loss of reputation. ${ }^{64}$ While a potential overlap with material damages, which - depending on the mode of calculation - also cover reputational losses, remains an issue, ${ }^{65}$ it emerges that corporate claimants may avail themselves of some form of moral damages in any event. Given the - controversial - practice to award moral damages for the suffering of a corporation's officers, ${ }^{66}$ there can be little doubt about the practical relevance of moral damages also under IIL. Indeed, the increasing number of cases making such claims ${ }^{67}$ confirms this conclusion.

62 James Crawford, State Responsibility - The General Part (Cambridge: Cambridge University Press 2013), 517, 528.

63 See ILC, ARSIWA with commentaries (n. 20), Art. 36, para. 16.

64 ICSID, Tecnicas Medioambientales Tecmed S. A. v. The United Mexican States, award of 29 March 2003, case no. ARB (AF)/00/2, para. 198; see also Irmgard Marboe, Calculation of Compensation and Damages in International Investment Law (2nd edn, Oxford: Oxford University Press 2017), para. 5.439.

65 See Borzu Sabahi, 'Moral Damages in International Investment Law: Some Preliminary Thoughts in the Aftermath of Desert Line v. Yemen' in: Jacques Werner and Arif Hyder Ali (eds), A Liber Amicorum: Thomas Wälde: Law Beyond Conventional Thought, Vol. 9, (London: CMP Publishing 2009), 253-264 (256 et seq.).

66 Notably, two corporate claimants successfully claimed moral damages for their employees' suffering, see ICSID, Desert Line v. Yemen (n. 3), para. 290 et seq.; ICSID, Rüdiger von Pezold et al.v. Zimbabwe (n. 3), paras 916, 923. Whether this approach is sound, e.g. as an exercise of 'corporate espousal' as proposed by Borzu Sabahi (see Sabahi (n. 27), 319 et seq.), is a contentious matter. Suffice it to say that it is in line with the approach taken by the European Court of Human Rights, ECtHR, Case of Comingersoll S. A. v. Portugal, judgment of 6 April 2000, no. 35382/97, para. 35 .

67 See for a discussion of the case law on moral damages infra II.1.a) and b). 


\section{Moral Damages and International Investment Law - A Disputed Arbitral Practice}

Bearing in mind the legal framework described above, the following part explores the development of an additional requirement for awarding moral damages in arbitral practice, i. e. exceptional circumstances. As will be shown, this criterion is now firmly entrenched in arbitral practice, while its precise contours are still developing (1.). Even though scholarly comments have disapproved of this development in a quite uniform manner, I will argue that this critique rests on a false assumption (2.).

\section{Arbitral Awards on Moral Damages - Exceptional Circum- stances as a Precondition for Moral Damages}

Any analysis of arbitral practice is confronted with the oftentimes whimsical nature of arbitral awards which do not seem to refer to each other, apply diverging understandings of the same concepts, or pursue completely different paths altogether. And yet, the practice on moral damages has been remarkably uniform after 2008. The starting point of this development has been the award in Desert Line v. Yemen ${ }^{68}$. Before Desert Line, only few investment cases dealt with claims for moral damages. Notably, they recognised the availability of this remedy under international law. ${ }^{69}$ However, they are of little relevance for the later development because later tribunals have almost exclusively relied on Desert Line and subsequent awards. In the aftermath of Desert Line, moral damages have been addressed in several disputes which led to the crystallisation of an exceptional circumstances threshold as a precondition for any award of moral damages (a). Interestingly, not all tribunals dealing with moral damages have referred to exceptional circumstances. Nevertheless, these awards are consistent with such a standard (b). As the emergence of such a standard is hence fairly certain, its exact meaning has been less clear. However, I suggest that there is indeed an emerging consensus on a three-tier test to evaluate the exceptionality of the circumstances in a given case (c).

\section{a) Exceptional Circumstances in Arbitral Practice}

In Desert Line v. Yemen, the tribunal arbitrated a claim by an Oman-based company against Yemen arising out of road construction works undertaken

68 ICSID, Desert Line v. Yemen (n. 3).

69 Libyan Arab Foreign Investment Company (LAFICO) v. The Republic of Burundi, award of 4 March 1991, ILR 96 (1994), 279, 329; ICSID, Tecmed v. Mexico (n. 64), para. 198. 
by said company. Among other claims, the company demanded moral damages for the repeated attacks on the construction site, the arrest of the employees, their mistreatment, and last but not least a loss of reputation. ${ }^{70}$ Instead of the vast amount claimed, the tribunal awarded 'only' one million USD for the moral damages suffered.

Two passages in the tribunal's reasoning stand out: Dealing with the possibility of claims for moral damages under IIAs, the tribunal held 'Even if investment treaties primarily aim at protecting property and economic values, they do not exclude, as such, that a party may, in exceptional circumstances, ask for compensation for moral damages. ${ }^{71}$ In addition, when deciding on the investor's claim for moral damages, the tribunal opined that 'the violation of the BIT by the Respondent, in particular the physical duress exerted on the executives of the Claimant, was malicious and is therefore constitutive of a fault-based liability. Therefore, the Respondent shall be liable to reparation for the injury suffered by the Claimant, whether it be bodily, moral or material in nature. ${ }^{72}$ These passages are important because read together, they imply that moral damages are only available in exceptional circumstances, which in turn requires a defendant State's 'malicious' behaviour of a certain magnitude. Alternatively, the passages could be read as a reference to the egregious behaviour of Yemen in the case decided without introducing a new legal standard. ${ }^{73}$

Despite the ambiguous language in Desert Line ${ }^{74}$ the first reading of the passages gained prominence in later practice, which conditions moral damages on a finding of exceptional circumstances. Over the course of various awards by and large applying this approach, ${ }^{75}$ a practice emerged which was

70 ICSID, Desert Line v. Yemen (n. 3), para. 286.

71 ICSID, Desert Line v. Yemen (n. 3), para. 289 (emphasis added).

72 ICSID, Desert Line v. Yemen (n. 3), para. 290 (emphasis added).

73 Wade M. Coriell and Silvia M. Marchili, 'Unexceptional Circumstances: Moral Damages in International Investment Law' in: Ian A. Laird and Todd J. Weiler (eds), Investment Treaty Arbitration and International Law, Vol. 3 (Huntington, New York: JURIS 2010) 213-231 (230); Sabahi (n. 66), 260 et seq.

74 Patrick Dumberry, 'Moral Damages' in: Marc Bungenberg, Jörn Griebel, Stephan Hobe and August Reinisch (eds), International Investment Law - A Handbook (Baden-Baden: Nomos 2015), 1130-1141 (1135); similarly Blake (n. 10), 394.

75 ICSID, Waguib Elie Goerge Siag and Clorinda Vecchi v. The Arab Republic of Egypt, award of 1 June 2009, case no. ARB/05/15, para. 545 referring to 'extreme cases of egregious behaviour' as the threshold for claims for moral damages. The tribunal, however, apparently misconstrued moral damages and conflated it with punitive damages, see ibid. para. 545. See also ICSID, Europe Cement Investment E Trade S. A. v. Turkey, award of 13 August 2009, case no. ARB(AF)/07/2, para. 181; ICSID, Cementownia v. Turkey (n. 33), para. 169. The last cases are notably different in that they concern the defendant State's claims for moral damages (which were denied in both cases). Still, they refused these claims with reference to Desert Line v. Yemen. 
analysed and clarified by the tribunal in Lemire v. Ukraine in 2011. The United States (US) investor who was the majority shareholder of a Ukrainian music radio station inter alia sued Ukraine for a violation of the US-Ukraine IIA's fair and equitable treatment clause due to Ukraine's refusal to grant new radio licenses and its repeated searches of the company's offices. While the tribunal refused to grant moral damages, the tribunal concluded based on prior case law that moral damages are available under exceptional circumstances only. ${ }^{76}$ Importantly, the tribunal also took great pain to elucidate the content of this standard. ${ }^{77}$ While its elaboration on the contours of the standard has met some critique, the exceptional circumstances approach to moral damages was widely followed in subsequent awards. ${ }^{78}$ Some tribunals have based this finding on the corresponding submissions by both parties. ${ }^{79}$ Others simply cited prior awards. ${ }^{80}$ Only one award, Arif v. Moldova did not simply ground its application of an exceptional circumstances threshold in the jurisprudence constante of prior tribunals, but also suggested a rationale for establishing this threshold. ${ }^{81}$ Essentially, the tribunal argued that it would create unwarranted financial gains for the victim and distort the 'fundamental balance of the allocation of risks' if moral damages were allowed in any other

76 ICSID, Lemire v. Ukraine (n. 6), para. 326. Already in its prior decision on jurisdiction, the tribunal found that moral damages were available under exceptional circumstances only, ICSID, Lemire v. Ukraine, Jurisdiction (n. 9), para. 476.

77 See below II.1.c).

78 In chronological order: ICSID, Tza Yap Shum v. Peru (n. 9), para. 281; ICSID, Arif v. Moldova (n. 48), paras 584-592; SCC, Anatolie Stati, Gabriel Stati, Ascom Group S. A., Terra Raf Trans Traiding Ltd. v. The Republic of Kazakbstan, award of 19 December 2013, SCC arbitration V (116/2010), para. 1781 et seq.; ICSID, Antoine Abou Lahoud and Leila BounafehAbou Laboud v. Democratic Republic of the Congo, award of 7 February 2014, case no. ARB/ 10/4, para. 621; ICSID, OI Europe v. Venezuela (n. 33), paras 906-908; ICSID, Rüdiger von Pezold et al. v. Zimbabwe (n. 3), paras 908 et seq.; ICSID, Border Timbers Limited and others v. Zimbabwe, award of 28 July 2015, case no. ARB/10/25, para. 908 et seq.; ICSID, Quiborax S. A., Non Metallic Minerals S. A. and Allan Fosk Kaplun v. Bolivia, award of 16 September 2015, case no. ARB/06/2, para. 618; UNCITRAL, Oxus Gold PLC v. The Republic of Usbekistan, award of 17 December 2015, available at: <https://www.italaw.com>, para. 895; ICSID, Getma International, NCT Necotrans, Getma International Investissements, NCT Infrastructure E Logistique v. Guinea, award of 16 August 2016, case no. ARB/11/29, paras 453, 457; ICSID, Marco Gavazzi and Stefano Gavazzi v. Romania, award of 18 April 2017, case no. $\mathrm{ARB} / 12 / 25$, para. 289.

79 SCC, Anatolie Stati et al. v. Kazakhstan (n. 78), para. 1781; similarly UNCITRAL, Oxus Gold v. Uzbekistan (n. 78), para. 900.

80 ICSID, Tza Yap Shum v. Peru (n. 9), para. 281; ICSID, Rüdiger von Pezold et al. v. Zimbabwe (n. 3), para. 909; ICSID, Border Timbers et al. v. Zimbabwe (n. 78), para. 909; ICSID, Quiborax et al.v. Bolivia (n. 78), para. 618; ICSID, Lahoud and Lahoud v. DCR (n. 78), para. 621 et seq.; ICSID, Getma International and others v. Guinea (n. 78), para. 453 et seq. and ICSID, Gavazzi and Gavazzi v. Romania (n. 78), paras 290-293.

81 ICSID, Arif v. Moldova (n. 48), paras 584-592. 
cases than those where 'both the conduct of the violator and the prejudice of the victim are grave and substantial'. ${ }^{82}$ What is still missing though, is a basis for introducing such a standard in positive law. Despite this shortcoming, a tendency to award moral damages under exceptional circumstances only emerges from this as well as the other awards.

\section{b) Arbitral Practice not Referring to Exceptional Circumstances}

Of course, there are more awards addressing moral damages than those dealt with so far..$^{83}$ None of those awards, however, contradicts the exceptional circumstances standard. Only three of them awarded some form of reparation for moral harm without requiring exceptional circumstances. ${ }^{84}$ As these three cases raise doubts as to the consistency of arbitral practice, I will address them in more detail before arguing that the other awards squarely fall in three categories, which are all consistent with an exceptional circumstances standard.

82 ICSID, Arif v. Moldova (n. 48), para. 592. This reasoning is rather peculiar because it revisits an argument stemming from classic contract law against the availability of moral damages, a fact the tribunal acknowledges itself. See on the non-availability of moral damages for a party's mere frustration in a contractual relationship under German contract and tort law: Gottfried Schiemann, ' $\mathbb{} 253$ BGB' in: Dagmar Kaiser (ed.), J von Staudingers Kommentar zum Bürgerlichen Gesetzbuch mit Nebengesetzen (Berlin: Sellier De Gruyter 2017), para. 6.

83 To the best of the author's knowledge, there are 14 further (published) awards which in one way or another mention moral damages without raising or applying an exceptional circumstances requirement. In chronological order: LAFICO v. Burundi (n. 69), 329 et seq.; ICSID, Tecmed v. Mexico (n. 64), para. 198; ICSID, Victor Pey Casado et Fondation 'Presidente Allende' v. Chile, award of 8 May 2008, case no. ARB/98/2, para. 704; ICSID, Biwater Gauff (Tanzania) Limited v. Tanzania, award of 24 July 2008, case no. ARB/05/22, para. 808; ICSID, Bernardus Henricus Funnekotter and others v. Zimbabwe, award of 22 April 2009, case no. ARB/05/6, para. 140; ICSID, M. Meerapfel Söhne AG v. Central African Republic, award of 12 May 2011, case no. ARB/07/10, paras 423-435; ICSID, Inmaris Perestroika Sailing Maritime Services GmbH and Others v. Ukraine, award of 1 March 2012, case no. ARB/08/8, para. 428; ICSID, Swisslion DOO Skopje v. Macedonia, award of 6 July 2012, case no. ARB/09/16; ICSID, The Rompetrol Group N. V.v. Romania, award of 6 May 2013, case no. ARB/06/3, paras 289, 293; PCA, ST-AD GmbH v. Bulgaria, award on jurisdiction of 18 July 2013, case no. 2011-06 (ST-BG), para. 430; UNCITRAL, Valeri Belokon v. Kyrgyzstan, award of 24 October 2014, available at: <https://www.italaw.com>, para. 317 et seq.; ICSID, Hassan Awdi, Enterprise Business Consultants, Inc. and Alfa El Corporation v. Romania, award of 2 March 2015, case no. ARB/10/13, paras 516, 22; ICSID, Lundin Tunisia B. V.v. Tunesia, award of 22 December 2015, case no. ARB/12/30, paras 374 et seq.; ICSID, Victor Pey Casado et Fondation 'Presidente Allende' v. Chile (Resubmission), award of 3 September 2016, case no. ARB/98/2, para. 243.

84 LAFICO v. Burundi (n. 69), 329 et seq.; ICSID, Swisslion v. Macedonia (n. 83), para. 350; UNCITRAL, Belokon v. Kyrgiyzstan (n. 83), para. 318. 
All of these 'deviant' awards, if looked at more closely, do not question the result reached from analysing the awards applying an exceptional circumstances standard. Regarding the first of these awards, LAFICO v. Burundi, it is pertinent to bear in mind that the claimant, LAFICO, was a Libyan Stateowned company. This company claimed (and received) moral damages on behalf of two of its managers (themselves Libyan nationals) whom Burundi had expelled. Thus, the dispute for all practical purposes resembles an interState dispute where the State brings a claim for moral damages on behalf of its national by way of diplomatic protection..$^{85}$ In line with the content of State responsibility between States outlined above, ${ }^{86}$ it seems plausible not to require exceptional circumstances. Besides, LAFICO was decided back in 1991 and thus, predates Desert Line considerably. Therefore, the award can hardly be expected to reflect a much later development.

The second case, Swisslion v. Macedonia, concerns a Swiss investor's claims against the expropriation of his majority shareholdings in a cookie factory without any compensation. Interestingly, the investor successfully claimed damages for a loss of reputation, ${ }^{87}$ which it had claimed under the rubric of moral damages. ${ }^{88}$ However, the tribunal only calculated the 'reputational damages' as a material, that is to say patrimonial, harm. ${ }^{89}$ Given the often patrimonial nature of such a harm for corporations, ${ }^{90}$ this is not surprising. In any case, by treating the loss of reputation as a material harm, ${ }^{91}$ the award is consistent with the practice on an exceptional circumstances standard, which only requires such a threshold for moral damages.

Thirdly, the tribunal in Belokon v. Kyrgyzstan held that any reputational harm of the investor is remedied by the findings of the tribunal.92 The case was concerned with the government administration of a Bank owned by Mr. Belokon and repeated allegations of misconduct against him as well as the Bank. Even though the tribunal did not elaborate a standard for awarding moral damages, this is not incompatible with the general practice. Perhaps, the tribunal implicitly applied an exceptional circumstances standard and

85 See for the relevance of the State ownership of LAFICO for the legal assessment also Patrick Dumberry, 'Satisfaction as a Form of Reparation for Moral Damages Suffered by Investors and Respondent States in Investor-State Arbitration Disputes', Journal of International Dispute Settlement 3 (2012), 1-38, (18 et seq.).

86 See supra under I.2.a).

87 ICSID, Swisslion v. Macedonia (n. 83), para. 73.

88 ICSID, Swisslion v. Macedonia (n. 83), para. 73.

89 ICSID, Swisslion v. Macedonia (n. 83), para. 350.

90 See on the overlap between material and moral damages regarding a loss of reputation supra n. 65.

91 See on the accuracy of this approach Moyano García (n. 10), 508 et seq.

92 UNCITRAL, Belokon v. Kyrgiyzstan (n. 83), para. 318. 
when concluding that those circumstances did not prevail in the case, considered the finding of a violation to be sufficient to remedy any moral harm that might have occurred. ${ }^{93}$

The remaining awards either rejected a claim for moral damages on procedural grounds, ${ }^{94}$ for lack of proof, ${ }^{95}$ or applied another threshold for awarding moral damages such as requiring 'malicious' acts. ${ }^{96}$ All these findings are in line with an exceptional circumstances standard either because there was no necessity to elaborate on such a standard for reasons of judicial economy, or because they apply a similar standard.

As a result, there is a strong practice applying an exceptional circumstances standard as a requirement for awarding moral damages. Notably, other tribunals have not objected to this approach. Thus, it is fair to assume that arbitral practice does require exceptional circumstances although the legal basis for doing so has remained unclear. Naturally, the emergence of such a requirement raises the question what exceptional circumstances means in practice. The next part will shed some light on the possible content of the standard.

\section{c) The Contours of Exceptional Circumstances}

Exceptional circumstances is a fairly vague notion which must be given some content to become operational. The most influential elaboration of this standard was delivered by the tribunal in Lemire v. Ukraine. Analysing the facts in Desert Line v. Yemen, Lusitania, and Siag v. Egypt, it proposed the following definition: ${ }^{97}$

'333. The conclusion which can be drawn from the above case law is that, as a general rule, moral damages are not available to a party injured by the wrongful acts of a State, but that moral damages can be awarded in exceptional cases, provided that

93 This very much resembles the practice of the European Court of Human Rights, see infra under III.2.a).

94 ICSID, Funnekotter v. Zimbabwe (n. 83), para. 140 (belated claim for moral damages); ICSID, Biwater Gauff v. Tanzania, award (n. 83), para. 808 (no claim for moral damages).

95 ICSID, Tecmed v. Mexico (n. 64), para. 198; ICSID, Pey Casado v. Chile (n. 83), para. 704; ICSID, Rompetrol v. Romania (n. 83), paras 289, 293; ICSID, Hassan Awdi et al. v. Romania (n. 83), paras 516, 22; ICSID, Lundin v. Tunesia (n. 83), para. 375; ICSID, Pey Casado v. Chile (Resubmission) (n. 83), para. 243.

96 ICSID, Meerapfel Söhne AG v. CAR (n. 83), paras 423-435; ICSID, Inmaris et al. v. Ukraine (n. 83), para. 428; PCA, $S T-A D$ v. Bulgaria (n. 83), para. 430.

97 ICSID, Lemire v. Ukraine (n. 6), paras 327-332. 
- the State's actions imply physical threat, illegal detention or other analogous situations in which the ill-treatment contravenes the norms according to which civilized nations are expected to act;

- the State's actions cause a deterioration of health, stress, anxiety, other mental suffering such as humiliation, shame and degradation, or loss of reputation, credit and social position; and

- both cause and effect are grave or substantial. ${ }^{98}$

Under this standard, it becomes clear that exceptional circumstances are present only if the State's conduct and the consequences flowing from this act are serious, which is, for instance, the case for a violent assault or detention of the investor. ${ }^{99}$ By circumscribing possible instances of State conduct and consequences, the standard is indeed easier to apply. ${ }^{100}$

Despite its practical advantages, the tribunal's reasoning is certainly subject to critique because the analysis rests on a rather small set of cases. ${ }^{101}$ Hence, the rather critical appraisal of Lemire in Arif v. Moldova comes as no surprise. The tribunal commented that the finding in Lemire v. Ukraine was not a definition of exceptional circumstances, but rather 'a summary of the issues in these cases, but it should not be taken as a cumulative list of criteria that must be demonstrated for an award of moral damages'.102 Also relying on Lusitania, the tribunal in Arif defined exceptionality by distinguishing 'mere breach' from 'a breach causing grave and substantial pain and suffering'. ${ }^{103}$ This test, however, is rather vague and besides, it is difficult to spot anything more than a slight deviation from Lemire. ${ }^{104}$

Despite its apparent weaknesses, the standard elaborated in Lemire found widespread support in arbitral practice. ${ }^{105}$ In contrast, only one other tribunal endorsed the approach in Arif. ${ }^{106}$ As any difference between Lemire and Arif

98 ICSID, Lemire v. Ukraine (n. 6), para. 333.

99 See, e. g. the circumstances in ICSID, Desert Line v. Yemen (n. 3), para. 286.

100 See the positive assessment of the test by Weber (n. 5), 447.

101 In addition, the Lusitania decision does not in and of itself support a higher threshold for awarding moral damages. See on the problems of deducing an 'exceptional circumstances' standard from this and other inter-State cases infra III.1.

102 ICSID, Arif v. Moldova (n. 48), para. 590.

103 ICSID, Arif v. Moldova (n. 48), paras 591, 603.

104 Moyano García (n. 10), 500; Dumberry (n. 5), 156.

105 ICSID, Tza Yap Shum v. Peru (n. 9), para. 281; ICSID, OI Europe v. Venezuela (n. 33), paras 906-910; ICSID, Rüdiger von Pezold et al. v. Zimbabwe (n. 3), para. 909; ICSID, Quiborax et al. v. Bolivia (n. 78), para. 618; ICSID, Border Timbers et al. v. Zimbabwe (n. 78), paras 896-900; ICSID, Gavazzi and Gavazzi v. Romania (n. 78), para. 292; see for a list of cases applying the Lemire standard Dumberry (n. 5), 154, n. 71.

106 ICSID, Lahoud and Lahoud v. DCR (n. 78), para. 622; see also the sympathetic discussion by Marboe (n. 10), 64 in light of the award's refutation of the Lemire standard. 
is only marginal, ${ }^{107}$ arbitral practice may be fairly summarised in equating exceptional circumstances with a gravity threshold: The act violating the IIA as well as its consequences must be either 'grave or substantial', whereas it remains unclear if this requires a certain mens rea on the side of the State, i. e. intent.

\section{The Discontents of the Critique in the Literature}

As already indicated, this turn in arbitral practice has not remained uncommented. The critique is almost unanimous in its condemnation of the exceptional circumstances standard ${ }^{108}$ while giving various explanations for this finding. Before other awards had followed up upon Desert Line, explaining the language in the award as an, admittedly, ambiguous assessment of the amount of moral damages ${ }^{109}$ sounded promising. After Lemire and the following awards, this argument lost its persuasiveness as arbitral practice had unequivocally introduced a threshold-test for awarding moral damages. However, other explanations did not lose their purchase with arbitral practice unfolding: While some blamed the tribunals for misunderstanding older case law ${ }^{110}$ others suspected an undue influence by human rights law ${ }^{111}$ or a reaction to the current backlash against IIL. ${ }^{112}$ Irrespective of the merits of each explanation, they all share the position that the requirement of exceptional circumstances is erroneous because it deviates from general international law. ${ }^{113}$

Notwithstanding any argument on an implicit exceptional circumstances standard under general international law, which will be explored below, ${ }^{114}$ the premise underlying the argument in the literature is unsound. It assumes

107 See on the similarity of threshold the Marboe (n. 64), para 5.358.

108 See the references supra n. 10. Notably, a recent monograph argues that arbitral practice simply engaged in a form of judicial law making ('Rechtsfortbildung'), which does no more than specifying the content of a rule, see von Bargen (n. 5), 58 et seq. While this assessment is indeed plausible with regard to quantifying the amount of moral damages due, it seems very difficult to argue that a flat contradiction of the overarching principle of full reparation (a point which von Bargen concedes, see von Bargen (n. 5), 104 et seq.) could be a specification in that sense.

109 Sergey Ripinsky and Kevin Williams, Damages in International Investment Law (London: British Institute of International and Comparative Law 2008), 309.

110 Dumberry and Cusson (n. 10), 62 et seq.

111 Coriell and Marchili (n. 73), 223.

112 Blake (n. 10), 380.

113 Blake (n. 10), 378; Dumberry (n. 5), 157; Dumberry and Cusson (n. 10), 54; Vasudev (n.

5), 107 et seq.

114 See infra III.1. 
that the rules on moral damages are (and have to be) identical under general international law, that is inter-State law, and for the responsibility vis-à-vis an individual, as is the case under IIL. As I will show, this is not necessarily the case.

To unpack the rules applicable to individual claims of State responsibility requires some preliminary remarks. First, the ARSIWA do not address the content of such claims (Art. 33(2) ARSIWA), but only deal with inter-State responsibility. Secondly, IIL is different from traditional inter-State international law by allowing the investor, a non-State actor, to bring claims. While there is still some debate as to whether the investor has direct rights or is only bringing a claim on behalf of her or his State of nationality, this article bases its further arguments on the idea that investors do have international rights of their own. ${ }^{115}$ Under this assumption, the rules developed so far are prima facie inapplicable to the secondary rights of investors arising from a violation of an IIA pursuant to Art. 33(2) ARSIWA.

When searching for the applicable rules, courts and arbitral tribunals alike have referred to the ARSIWA as embodiment of the applicable rules of customary international law without further scrutiny also in cases of State responsibility towards the individual. ${ }^{116}$ Thus, it is fair to assume that the rules of State responsibility will be by and large the same as under general international law. This in line with the wording of the ARSIWA, which does not preclude their application to individual secondary rights. It is important to note at this point, however, that the application of the general rules of responsibility is an extension of an inter-State regime to claims of individuals. Hence, the rules will not be identical, but they need to be adapted to the specific situation of individual claims for reparation, if necessary. ${ }^{117}$ What this

115 See for the debate and arguments on investor rights Tillmann Rudolf Braun, 'Globalization-Driven Innovation: The Investor as a Partial Subject in Public International Law - An Inquiry into the Nature and Limits of Investor Rights', The Journal of World Investment \& Trade 15 (2014), 73-116; Peters (n. 22), 282-338 (both in favour of 'direct' investor rights).

116 See for investment arbitration Martins Paparinskis, 'Investment Treaty Arbitration and the (New) Law of State Responsibility', EJIL 24 (2013), 617-647 (620); for the practice under the ECHR e.g. ECtHR (Grand Chamber), Case of Verein gegen Tierfabriken Schweiz (VgT) v. Switzerland (No. 2), judgment of 30 June 2009, no. 32772/02, para. 86.

117 James Crawford, 'International Protection of Foreign Direct Investments: Between Clinical Isolation and Systematic Integration' in: Rainer Hofmann and Christian J. Tams (eds), International Investment Law and General International Law - From Clinical Isolation to Systemic Integration (Baden-Baden: Nomos 2011), 17-28 (25); Peters (n. 22), 174; Stephan Wittich, 'State Responsibility' in: Marc Bungenberg, Jörn Griebel, Stephan Hobe and August Reinisch (eds), International Investment Law - A Handbook (Baden-Baden: Nomos 2015), 23-45 (44 et seq.); see also Zachary Douglas, 'The Hybrid Foundations of Investment Treaty Arbitration', BYIL 74 (2004), 151-289 (189) who, however, stresses the distinctiveness of IIL. 
means in practice is well illustrated by the remedy of satisfaction (Art. 37 ARSIWA). Under the ARSIWA, satisfaction covers moral harm done to a State. ${ }^{118}$ It is concerned with the dignity of States and thus, one would have to adapt this concept if one were to apply it to individuals.

Accordingly, the rules applicable to secondary rights under IIL are largely the same as under general international law subject, of course, to possible leges specialis in the treaties concerned, which is only rarely the case $\mathrm{e}^{119}$ and possible adjustments due to the individual as claimant. Crucially, the application of the same rules is not a given, but it is subject to the individual rule concerned. Thus contrary to the view held in the literature, the deviation from general international law in and of itself cannot serve as an argument for or against the arbitral practice. ${ }^{120}$ Rather, the question is whether arbitral practice does reflect a rule of (customary) international law on State responsibility towards the individual (without explicitly saying so). I will argue in the next section that this is indeed the case.

\section{Reconciling Exceptional Circumstances with International Law}

The prior section argued that the literature in paralleling general international law and IIL regarding the content of State responsibility made too sweeping an assumption. But if the exceptional circumstances standard cannot be discarded that easily anymore, the question whether exceptional circumstances find some legal basis under international law, becomes even more urgent. This is all the more the case because arbitral practice itself fails to ground its approach in international law, perhaps apart from arguing that this approach is consistent with Lusitania. ${ }^{121}$

This section will approach this task from two directions. First, it will explore whether general international law does contain an implicit exceptional circumstances standard. Because several reasons militate against such an understanding, I will secondly argue that the exceptional circumstances rule reflects an at least emerging rule of customary international law.

118 See Crawford (n. 62), 517, 528.

119 See supra I.2.

120 Admittedly, the literature also advances further, perhaps best termed teleological, reasons for the application of the same rule, see Dumberry (n. 5), 157 et seq. Those concerns will be addressed infra III.2.b).

121 See, for instance, Arif v. Moldova (n. 48), para. 591. 


\section{An Implicit Exceptional Circumstances Standard Under General International Law?}

Even though I argued above that no award under general international law so far explicitly subjected moral damages to an additional threshold such as exceptional circumstances, it is worth noting that the little reasoning usually provided by arbitral tribunals for requiring exceptional circumstances is a reference to Lusitania. ${ }^{122}$ Prominently, the tribunal in Arif v. Moldova rooted exceptional circumstances explicitly in general international law. ${ }^{123}$ Whereas this conclusion finds no basis in the reasoning of the Umpire in Lusitania itself, it is not difficult to see why one could reach such a conclusion. Indeed, the cases under general international law are largely characterised by circumstances one would deem exceptional: ${ }^{124}$ the sinking of an ocean liner with civilian passengers on board in Lusitania or the arrest, detention, and eventual expulsion of Mr. Diallo in the ICJ's Diallo Case. ${ }^{125}$ Moreover, the $M / V$ Saiga Case concerned the illegal boarding, arrest, and detention of the Saiga, which involved indiscriminate use of firearms by Guinean officials resulting in severe personal injury. ${ }^{126}$ Yet, one might wonder whether these cases justify the conclusion that moral damages are indeed an exceptional remedy. ${ }^{127}$ Despite its intuitive attractiveness, I offer four reasons why these cases do not support such a sweeping conclusion.

First, such a threshold conflicts with the principle underlying the regime of reparation under international law, that is full reparation as enshrined in Chorzów Factory. ${ }^{128}$ Thus, one would expect the ICJ or other tribunals to make an explicit exception to such a fundamental principle if they indeed intended to limit moral damages to exceptional circumstances.

Secondly, a broader analysis of the case law under general international law reveals that not all decisions are necessarily consistent with an exceptional circumstances standard. For instance in the Duzgit Integrity Arbitration, Malta successfully claimed moral damages for the prolonged detention

122 See ICSID, Desert Line v. Yemen (n. 3), para. 289; ICSID, Lemire v. Ukraine (n. 6), para. 329 et seq.; ICSID, Arif v. Moldova (n. 48), para. 591.

123 See ICSID, Arif v. Moldova (n. 48), 584; see for an approving discussion De Brabandere (n. 36), 199 et seq.

124 Dumberry and Cusson (n. 10), 56-62.

125 ICJ, Diallo, compensation (n. 47), para. 21.

126 See ITLOS, M/V Saiga (n. 56), para. 158.

127 Cf. regarding Diallo: Guigo Wang, 'Issues of Compensation for Non-Expropriatory Breaches in International Investment Law', Manchester Journal of International Economic Law 11 (2014), 156-181 (175 and 178).

128 PCIJ, Chorzów Factory Case (n. 35), 47; see also Dumberry (n. 5), 157. 
of the vessel with the crew on board as well as the internationally wrongful conviction of the shipmaster. ${ }^{129}$ Importantly for present purposes, the tribunal noted that there was no ill-treatment of the crew, which was used to be on the ship far from home for a considerable period. ${ }^{130}$ Thus, even bearing in mind the length of the detention of the vessel (214 days), ${ }^{131}$ the harm was considerably less grave or substantial than in Lusitania or Desert Line. Along similar lines, Panama requested moral damages for the 'significant psychological stress and expense[s] ... to engage lawyers in their defense in the criminal proceedings' ${ }^{\prime 32}$ in the $M / V$ Norstar Case. While ITLOS refused to award moral damages for a lack of causation, the submission indicates that at least Panama considers these minor forms of moral harm to be susceptible of moral damages.

Thirdly, there is an easy explanation for the relative frequency of rather exceptional circumstances in general international law cases discussing moral damages. All these claims were brought by way of diplomatic protection, which requires a State to decide to take a decision on taking up the claim. Under international law, a State enjoys a wide discretion to exercise this right. ${ }^{133}$ Given the political, diplomatic, and other potential ramifications of such a decision, it stands to reason that a State would do this only in case of claims of a sufficient gravity. Thus, a form of 'selection bias' can easily account for the configuration of the cases. In turn, deducing an exceptional circumstances standard under general international law solely from the facts of the case would seem too far-fetched.

Fourthly, if anything, one might infer from the case law that moral damages will be readily awarded in certain factual circumstances without, however, explicitly excluding other circumstances. Wrongful detention is such a scenario. ${ }^{134}$ This resonates well with the ICJ's remark in Diallo on the presumption in favour of moral harm as a result of the violations found..$^{135}$ Thus, a more plausible reading of the cases would be to argue that moral

129 PCA, Duzgit Integrity Reparations (n. 58), para. 183.

130 PCA, Duzgit Integrity Reparations (n. 58), para. 184.

131 PCA, Duzgit Integrity Reparations (n. 58), para. 184.

132 Submission by Panama cited according to ITLOS, The M/V 'Norstar' Case (Panama v. Italy), judgment of 10 April 2019, case no. 25, para. 450.

133 ICJ, Barcelona Traction, Light and Power Company, Limited (Belgium v. Spain) (New Application: 1962), judgment of 5 February 1970, I.C.J. Reports 1970, 3, 44; see on the development towards a duty to exercise diplomatic protection: International Law Commission, Draft Articles on Diplomatic Protection with commentaries of 2006, ILCYB 2006, Vol. II, Part Two, 26, Art. 2 para. 3 and Art. 19; see also Peters (n. 22), 396-407.

134 See, e. g. PCA, Arctic Sunrise (n. 2), para. 394.

135 ICJ, Diallo, compensation (n. 47), para. 21. 
harm will be presumed under those circumstances (which one may very well term 'exceptional').

For these reasons, the better view is to regard exceptional circumstances as a deviation from general international law. As I will argue in the subsequent section, this does not mean that the standard lacks a legal basis. Rather, it has a basis of its own in an at least emerging rule of customary international law.

\section{Exceptional Circumstances as an Emerging Rule of Customary International Law}

Identifying exceptional circumstances as an emerging rule of customary international law requires a two-step argument. First, I will argue that there is enough evidence to find that such a rule of customary international law is at least emerging (a)). Despite the strong arguments in favour of such a rule, it is difficult to understand why moral harm should be subject to a more restrictive rule than material harm. Therefore, I will explain in a second step why this rule also makes sense within IIL (b)). This, in turn, also reinforces the argument on the customary status of the rule as it may be deduced from the overarching principles of IIL.

\section{a) The Emergence of a New Rule of Customary International Law}

According to orthodox view, the emergence of a rule of customary international law presupposes an established practice that is supported by a corresponding conviction to act in accordance with a legal duty. ${ }^{136} \mathrm{~A}$ shorter period of time may suffice if the practice is 'both extensive and virtually uniform' ${ }^{137}$ I submit that there is a strong tendency to subject the compensation of moral damages to an exceptional circumstances standard, at least under IIL.

The practice of States on moral damages in IIL is impressive given the short period of time since moral damages have played a more prominent role in this regime. ${ }^{138}$ Some States even argued for an exceptional circumstances

136 Art. 38 para. 1 lit. b ICJ-Statute; see also ICJ, North Sea Continental Shelf (Germany v. Denmark / Germany v. Netherlands), judgment of 20 February 1969, I.C.J. Reports 1969, 3, para. 77.

137 ICJ, North Sea Continental Shelf (n. 136), para. 74.

138 See supra II.1. 
standard in arbitration proceedings. ${ }^{139}$ These eleven States include Ukraine, Peru, Moldova, Bulgaria, Kazakhstan, Democratic Republic of the Congo, Romania, Oman, Uzbekistan, Guinea, and Bolivia. They cover four continents, that is Europe, Asia, Africa, and (South) America. Although eleven States is a rather small number if compared to the total number of States, it is remarkable that this practice has met with no resistance ${ }^{140}$ and is so broad despite its relative brevity.

To boot, arbitration practice as a subsidiary source of international law within the meaning of Article 38 para. 1 lit. d) ICJ-Statute supports this position. One might object to this argument that arbitral practice does not ground itself in any source of international law, let alone custom. Though deplorable, this is line with the general practice in investment arbitration to refer to other awards as a persuasive authority rather than to the formal sources of international law. ${ }^{141}$ At least, the practice supports the emergence of such a rule because tribunals necessarily imply that the exceptional circumstances standard has a basis in international law when applying it (otherwise, they would lack a mandate to apply the rule). Another rather indicative fact is the behaviour of investors. Though generally disadvantaged by the requirement of exceptional circumstance, they have largely argued in favour of such a feature in their submissions. ${ }^{142}$ Due to their status under international law, the investors' practice is irrelevant for the formation of custom

139 See ICSID, Lemire v. Ukraine (n. 6), para. 319; ICSID, Tza Yap Shum v. Peru (n. 9), para. 277; ICSID, Arif v. Moldova (n. 48), paras 587-588; ICSID, Convial Callao S. A. y CCICompañia de Concesiones de Infraestructura S. A. v. Republic of Peru, award of 21 May 2013, case no. ARB/10/2, para. 357; PCA, ST-AD v. Bulgaria (n. 83), para. 250 (though with respect to the respondent State's claim to moral damages); SCC, Anatolie Stati et al. v. Kazakbstan (n. 78), para. 1781; implicitly also in ICSID, Lahoud and Lahoud v. DCR (n. 78), para. 620; ICSID, Hassan Awdi et al. v. Romania (n. 83), para. 501; ICSID, OI Europe v. Venezuela (n. 33), para. 902; ICSID, Adel A Hamadi Al Tamimi v. Sultanate of Oman, award of 3 November 2015, case No ARB/11/33, paras 254-256; UNCITRAL, Oxus Gold v. Uzbekistan (n. 78), para. 900; ICSID, Quiborax et al. v. Bolivia (n. 78), para. 609; ICSID, Getma International and others v. Guinea (n. 78), para. 417.

140 To the best of the other's knowledge, no State - especially traditionally capital exporting States - objected to the introduction of an 'exceptional circumstances' standard.

141 See on the role of precedent in IIL Stephan W. Schill, 'Sources of International Investment Law: Multilateralization, Arbitral Precedent, Comparativism, Soft Law' in: Jean d'Aspremont and Samantha Besson (eds), The Oxford Handbook of the Sources of International Law (Oxford: Oxford University Press 2017) 1095-1115 (1103-1106).

142 ICSID, Arif v. Moldova (n. 48), para. 587; SCC, Anatolie Stati et al. v. Kazakbstan (n. 78), para. 1781; ICSID, Renée Rose Levy de Levi v. The Republic of Peru, award of 26 February 2014, case no. ARB/10/17, para. 277; ICSID, Rüdiger von Pezold et al. v. Zimbabwe (n. 3), para. 897; presumably also ICSID, Getma International and others v. Guinea (n. 78), para. 400 (though citing diverging views in the literature). 
according to conventional views. ${ }^{143}$ Nevertheless, it is rather conspicuous if even the parties disadvantaged by the rule adhere to it.

There are also indications of an opinio iuris. In this regard, it is important to note that States referred to exceptional circumstances in a specifically legal context, i.e. in arbitration. In doing so, they indicate that they consider themselves bound in this respect. Although procedural tactics also motivate party submissions in arbitral proceedings, this does not ipso facto diminish their value as a proof of opinio iuris. Accordingly, also the International Law Commission has considered party submissions to be a suitable source for the determination of custom. ${ }^{144}$ Even if one were sceptical towards invoking party submissions to infer a new rule of custom, it is interesting to note that States have even felt bound by the exceptional circumstances rule in the rare cases in which they themselves have claimed moral damages. ${ }^{145}$ If States had only adopted exceptional circumstances as a standard because it suits their interests, nothing would have been easier than advancing a different standard for their own claims. With respect to the defendant States' own claims, due to a lack of sufficient practice, a corresponding rule has probably not yet emerged, though. Yet, this behaviour shows that States do not act according to procedural tactics, but out of a genuine feeling of legal duty. Consequently, there is every indication that a corresponding rule of customary international law has emerged or is at least currently emerging.

Looking outside the narrow confines of IIL, the practice in regional human rights systems also furnishes some support for the argument advanced here. This practice is relevant because all regional human rights courts have grounded the assessment of compensation on general international law, i. e. customary international law. ${ }^{146}$ Despite the basis for awarding monetary

143 ILC, Draft conclusions on identification of customary international law, with commentaries of 2018, A/73/10, Conclusion 4 paras 1, 3 .

144 Michael Wood, Second report on identification of customary international law, (2014) A/CN4/672, para. 75; see also Gleider Hernández, International Law (Oxford: Oxford University Press 2019), 41.

145 PCA, ST-AD v. Bulgaria (n. 83), para. 250. Notably, the investor did not claim moral damages. Thus, the State's position was not motivated by considerations of consistency.

146 Matthieu Loup, 'The Content of State Responisibility under the European Convention on Human Rights - Some Reflections on the Court's Approach to General International Law on State Responsibility' in: Samantha Besson (ed.), International Responsibility (Genf and Zurich: Schulthess 2017), 139-158 (157); IACtHR, Case of Velásquez-Rodríguez v. Honduras (Reparations and Costs), judgment of 21 July 1989, Serices C no. 7, para. 25; AfCtHPR, Beneficiaries of late Norbert Zongo et al. v. Burkina Faso, Ruling on Reparation of 5 June 2015, app. no. 013/2011, paras 20-22. 
compensation in treaty clauses, ${ }^{147}$ their handling of moral damages can thus evidence the emergence of a customary norm.

In the major regional human rights systems, which provide for some form of an individual right of complaint, claimants may recover moral damages. ${ }^{148}$ Interestingly, in all of these systems, the courts recognise instances of moral harm that are not sufficiently serious to receive a pecuniary award. Hence, it resembles the practice in IIL. ${ }^{149}$ The best-known example is the European Court of Human Rights' practice to limit the award of just satisfaction to the finding of a violation. ${ }^{150}$ Although the reasons for such a finding are rather opaque, it seems linked to the relatively minor character of the moral harm involved. ${ }^{151}$ To a lesser extent, Inter-American and African practice also reflect this approach. ${ }^{152}$

Grounding the exceptional circumstances rule in an analogy to human rights law has met staunch resistance in IIL literature. Indeed, the salience of arguments derived from human rights law in IIL has become a highly contested issue. ${ }^{153}$ Whatever position one may take in this debate, one should carefully weigh the commonalities and differences between the two subregimes of international law before drawing any parallels. That being said, there is reason to argue in favour of a common approach that minds the differences. While both have very different goals, ${ }^{154}$ they converge to some extent when faced with moral damages. Both have to deal with a potentially

147 Art. 41 European Convention on Human Rights of 4 November 1950, CETS No. 5; Art 63 American Convention on Human Rights of 22 November 1969, 1144 UNTS 1978; Art. 27(1) Protocol to the African Charter on Human and Peoples' Rights on the Establishment of an African Court on Human and Peoples' Rights of 10 June 1998, OAU Doc. OAU/LEG/ EXP/AFCHPRIPROT(III).

148 See, e.g. AfCHPR, Rev. Christopher R. Mtikila v. The United Republic of Tanzania, ruling on reparations of 13 June 2014, app. no. 011/2011, para. 33; ECtHR, Abu Zubaydah v. Lithuania, judgment of 31 May 2018, no. 46454/11, para. 688; IACtHR, Gutiérrez-Soler v. Colombia, judgment on merits, reparations and costs of 12 September 2005, Series C no. 132, para. 64.

149 See for a different reading of human rights jurisprudence Blake (n. 10), 395-398.

150 Dinah Shelton, Remedies in International Human Rights Law (3rd edn, Oxford: Oxford University Press 2015), 287-295.

151 ECtHR (Grand Chamber), Varnava and others v. Turkey, judgment (merits and just satisfaction) of 18 September 2009, nos 16064/90, 16065/90, 16066/90, 16068/90, 16069/90,16070/ 90, 16071/90, 16072/90 and 16073/90, para. 224; Octavian Ichim, Just Satisfaction under the European Convention on Human Rights (Cambridge: Cambridge University Press 2015), 118.

152 AfCHPR, Mtikila v. Tanzania (n. 148), para. 37; IACtHR, 'Street Children' (VillagranMorales et al.) v. Guatemala (Reparations and Costs), judgment of 26 May 2001, Series C no. 77, para. 88.

153 See on the debate Blake (n. 10), 388-393 arguing in favour of a cross-fertilisation from human rights law.

154 Protection of economic interests on the one hand and protection of individuals on the other hand. 
unlimited number of individual claims for moral damages. How to deal with these claims (and limit them) is thus a common problem. In light of the very different case numbers, different types of violations in question, and, again, different ultimate aims, the concrete solutions might be different (e.g. the threshold for awarding moral damages might be higher in IIL while it is lower in human rights law). But the point still stands that one can observe a confluence in different systems of individual claims processes under international law to limit the availability of moral damages to certain more serious cases. This development enforces the argument that a rule of customary international law is at least emerging that, in IIL, moral damages are only available under exceptional circumstances.

\section{b) The Rationale Behind the Rule}

From a strictly positivist perspective, it is close to irrelevant whether a rule makes sense. If States so wish, they may create rules of whatever content within certain boundaries, of course. However, as the customary rule in question might not yet have emerged, it is worthwhile to analyse its rationale to evaluate whether it is (or would likely be) a sensible rule. This need is augmented by arbitral tribunals' paucity of reasoning. ${ }^{155}$

On the search for a rationale, it is important to remember that the exceptional circumstances standard essentially introduces two distinctions. It subjects moral damages in IIL to a stricter requirement than material damages. Additionally, it treats moral damages differently from general international law. Looking for a rationale thus means explaining these differences. The reasons for both distinctions are distinct but interconnected. ${ }^{156}$

Regarding the different treatment of material and moral damages under IIL, a recourse to the object and purpose of IIL already gives a hint at the salience of the distinction. At their heart, IIAs are all about securing foreign (direct) investments. Accordingly, their purpose is to protect economic interests. Consequently, remedying moral damages is a merely accidental function of IIL and, in turn, it is only natural that those damages are remedied under exceptional circumstances only. ${ }^{157}$

155 See supra II.1.a).

156 See for a different view Dumberry and Cusson (n. 10), 55 et seq.

157 See for a similar argument - albeit with respect to a tribunal's jurisdiction ratione materiae - Ripinsky and Williams (n. 109), 311; see also Patrick Dumberry, 'Compensation for Moral Damages in Investor-State Arbitration Disputes', J. Int. Arb. 27 (2010), 247-276 (269), although he refuses to accept an additional requirement for awarding moral damages and simply refers to the paucity of such claims as a fact. 
As to the distinction between IIL and inter-State international law, I offer two tentative explanations. The first one relates to the number of (potential) claims and their effect on quantum. Generally speaking, inter-State cases are fewer than cases brought by individuals under IIL or human rights law. Yet, this does not relate to quantum at first sight. As I suggest, however, numbers do matter. While it is very well possible to remedy some isolated claims in an all-encompassing fashion, this is hardly feasible in the face of a potentially unlimited number of potential claims. ${ }^{158}$ Reflecting this logic, many municipal State liability regimes ${ }^{159}$ facing a similar situation seek to limit a State's liability. These restrictions apply at various levels and vary largely across the respective systems. But comparative studies suggest that, generally speaking, in many legal systems, State liability is more restrictive than the liability for commercial (or 'private') wrongs. ${ }^{160}$

The reference to municipal (public) law ties in well with the second tentative explanation. Understanding IIL as an emanation of public (state liability) law, as prominently suggested in the literature, ${ }^{161}$ may shed some light on the different treatment of moral damages in IIL and general international law. According to this view, IIL is a public law regime because it provides for a sovereign's liability for its public acts. ${ }^{162}$ In contrast, general international law in its classical configuration very much resembles a 'private law writ large'163 because it regulates the relationship between equals, i.e. States. These public/private law readings of general international law and IIL could, arguably, also translate into a different handling of damages for interState (that is to say essentially private) damages and individual-State damages (that are more akin to public wrongs). Again, a look into municipal laws,

158 See also EECC, Final Award - Ethiopia's Damages Claims, award of 17 August 2009, UNRIAA XXVI, 631, para. 61. Of course, this case was an inter-State arbitration that concerned a vast amount of individuals. The difference to individual complaint mechanisms, such as under IIL, lies in the fact that the latter applies to ex ante unknown scenarios while interState arbitrations are usually established only with regard to a specific dispute that has already surfaced, thereby limiting the amount of potentially concerned individuals.

159 Under this term, I refer to all those national legal rules which address a State's (or its subunit's) liability for sovereign acts (and not the liability for commercial acts).

160 See for Europe Oliver Dörr, ' $\$ 1$ Staatshaftung in Europa: Vergleichende Bestandsaufnahme' in: Oliver Dörr (ed.), Staatshaftung in Europa (Berlin and Boston: De Gruyter 2014), 130 (7).

161 See Gus Van Harten, Investment Treaty Arbitration and Public Law (Oxford: Oxford University Press 2007); Stephan W. Schill, 'International Investment Law and Comparative Public Law - An Introduction' in: Stephan W. Schill (ed.), International Investment Law and Comparative Public Law (Oxford: Oxford University Press 2010), 3-37.

162 Van Harten (n. 161), especially 58-71.

163 Thomas Eskine Holland, Studies in International Law (Oxford: Clarendon Press 1898), 152. 
which deal with both scenarios, merits attention. Indeed, some (European) state liability rules provide for other remedies than pecuniary damages to remedy moral harm ${ }^{164}$ and some also tie a monetary award for moral harm to additional, more restrictive requirements (if compared to patrimonial damages) such as fault, or an otherwise particularly serious violation of certain rights. ${ }^{165}$ The lesson to be learned from this comparative remark is rather simple: There is a tendency to limit the liability of a sovereign for public wrongs vis-à-vis the individual at least regarding moral harm. Applying this finding on the international plane, it would make sense to treat liability in inter-State law (which is basically a law between equals) differently from IIL, which in this respect resembles a regime of State liability.

\section{Conclusion}

Despite firm critique in the literature, exceptional circumstances have crystallised as an additional threshold for awarding moral damages under IIL. So far, however, this approach lacked a legal basis in international law. This article sought to fill this gap by arguing that the exceptional circumstances standard reflects an emerging rule of customary international law on the content of State responsibility towards the individual. Under this rule, moral damages are only available in IIL, if there are exceptional circumstances. While it might be too early to confirm such a status, also the rationales behind treating moral damages differently from general international law support the finding of this article. Treating moral damages differently is a common theme in other areas dealing with similar problems, be that human rights law or municipal State liability regimes. Additionally, the difference to inter-State law may be explained with the differences between a liability regime among equals and a regime between the individual and a sovereign State.

In reaching its conclusion, the article sought to contribute to the broader issue of the content of State responsibility towards the individual, which is yet an area of uncertainty. The article highlighted that the secondary rules on responsibility are not necessarily identical for general (inter-State) international law and those parts allowing for individual rights. From this vantage point, the application of similar rules is not a given and rather needs further analysis. While this provided the room to argue for a place of exceptional circumstances in the rules of reparation towards the individual, this in turn

164 Dörr (n. 160), 22.

165 Dörr (n. 160), 23. 
meant that the standard can also serve to elucidate the exact content of reparation towards the individual more generally. Thus, situating exceptional circumstances in the broader context of international law also allows for cross-fertilisation between different areas of international law providing for State responsibility towards the individual, notably human rights.

Whereas this article tried to situate arbitral practice on moral damages under IIL within international law, there are plenty of issues still unsettled. Most importantly, a question for further research will be the precise content of the exceptional circumstances standard. 